\title{
UV Irradiation of Skin Enhances Glycolytic Flux and Reduces Migration Capabilities in Bone Marrow-Differentiated Dendritic Cells
}

Terence A. McGonigle, ${ }^{*}$ Kevin N. Keane, ${ }^{\dagger}$ Simon Ghaly, ${ }^{*}$ Kim W. Carter, ${ }^{*}$ Denise Anderson, ${ }^{*}$ Naomi M. Scott, ${ }^{*}$ Helen S. Goodridge, ${ }^{\ddagger}$ Amy Dwyer, ${ }^{\S}$ Eloise Greenland, ${ }^{\S}$ Fiona J. Pixley, ${ }^{\S}$ Philip Newsholme, ${ }^{\dagger}$ and Prue H. Hart*

From the Telethon Kids Institute* and the Department of Pharmacology, ${ }^{\S}$ University of Western Australia, West Perth, Western Australia, Australia; the School of Biomedical Sciences, ${ }^{\dagger}$ Curtin Health Innovation Research Institute Biosciences, Curtin University, Perth, Western Australia, Australia; and the Board of Governors Regenerative Medicine Institute, ${ }^{\ddagger}$ Cedars-Sinai Medical Center, Los Angeles, California

Accepted for publication

June 1, 2017.

Address correspondence to Prue H. Hart, Ph.D., Telethon Kids Institute, PO Box 855, West Perth, WA 6872, Australia. E-mail: prue.hart@telethonkids.org.au.

\begin{abstract}
A systemic immunosuppression follows UV irradiation of the skin of humans and mice. In this study, dendritic cells (DCs) differentiating from the bone marrow (BM) of UV-irradiated mice had a reduced ability to migrate toward the chemokine ( $C-C$ motif) ligand 21 . Fewer DCs also accumulated in the peritoneal cavity of UV-chimeric mice (ie, mice transplanted with BM from UV-irradiated mice) after injection of an inflammatory stimulus into that site. We hypothesized that different metabolic states underpin altered DC motility. Compared with DCs from the BM of nonirradiated mice, those from UVirradiated mice produced more lactate, consumed more glucose, and had greater glycolytic flux in a bioenergetics stress test. Greater expression of 3-hydroxyanthranilate 3,4-dioxygenase was identified as a potential contributor to increased glycolysis. Inhibition of 3-hydroxyanthranilate 3,4-dioxygenase by 6-chloro-DL-tryptophan prevented both increased lactate production and reduced migration toward chemokine ( $C-C$ motif) ligand 21 by DCs differentiated from BM of UV-irradiated mice. UV-induced prostaglandin $E_{2}$ has been implicated as an intermediary in the effects of UV radiation on BM cells. DCs differentiating from BM cells pulsed in vitro for 2 hours with dimethyl prostaglandin $E_{2}$ were functionally similar to those from the BM of UV-irradiated mice. Reduced migration of DCs to lymph nodes associated with increased glycolytic flux may contribute to their reduced ability to initiate new immune responses in UV-irradiated mice. (Am J Pathol 2017, 187: 2046-2059; http://dx.doi.org/ 10.1016/j.ajpath.2017.06.003)
\end{abstract}

Dendritic cells (DCs) are efficient at antigen processing and presentation in lymph nodes, causing the recruitment and involvement of adaptive immune cells. As differences in the cellular and molecular phenotype of DCs can control the activation and polarization of effector and regulatory $\mathrm{T}$ cells, DCs can determine the strength of immune responses, and the balance between immunity and tolerance. ${ }^{1,2} \mathrm{DCs}$ require glycolytic metabolism for increased energy, ATP production, and survival, and differences in cellular metabolism of DCs have now been linked with their functional properties. $^{3-5}$

In both humans and experimental animals, UV irradiation of skin stimulates a systemic immunosuppression such that responses to antigens applied to nonirradiated sites are reduced. Skin exposure to UV radiation (UVR) stimulates multiple pathways that provoke the production of soluble molecules and the migration of immune cells (Langerhans cells, dermal DCs, and mast cells) to local lymph nodes. Recent reviews have covered the molecular and cellular basis of the suppression of systemic immune responses in UV-irradiated hosts. ${ }^{6,7}$ UVR, administered as a single

\footnotetext{
Supported by the National Health and Medical Research Council, Australia, grants 572660 and 1067209 (P.H.H.); Cancer Council Western Australia (P.H.H. and F.J.P.); Scott Kirkbride Melanoma Centre (P.H.H.); Asthma Foundation, Western Australia (P.H.H.); and McCusker Charitable Foundation Bioinformatics Centre (K.W.C.).

Disclosures: None declared.
} 
erythemal dose or multiple suberythemal doses, can signal via intermediates to myeloid progenitors in the bone marrow (BM). In turn, DCs differentiating from these progenitor cells in the BM have reduced immunogenic properties and poorly initiate new responses in naïve mice. ${ }^{8-10}$ The effect of UVR is long-lived because daughter DCs differentiating in response to Fms-related tyrosine kinase 3 ligand or granulocyte-macrophage colony-stimulating factor (GMCSF) with IL-4, from the BM of 16-week engrafted UVchimeric mice (ie, naïve mice transplanted with BM cells from UV-irradiated donor mice), are similarly inefficient at priming new immune responses.

In priming assays when antigen-loaded DCs are injected into ears of naïve mice, DCs differentiating in vitro from the BM of UV-chimeric mice, compared with those differentiating from control-chimeric mice, have a reduced ability to traffic to draining lymph nodes, and we have proposed that this contributes to their inefficiency to initiate new immune responses. In these experiments, we ruled out that there were fewer $\mathrm{CD} 11 \mathrm{c}^{+}$major histocompatibility complex class $\mathrm{II}^{+}$cells in the skin or lymph nodes of UV-chimeric mice before experimental challenges. ${ }^{9}$ However, when fluorescein isothiocyanate (FITC) was painted onto the dorsal skin of UV-chimeric mice, there was less hypertrophy of the skin-draining lymph nodes after 24 hours. This was associated with fewer FITC ${ }^{\text {hi }}$ major histocompatibility complex class $\mathrm{II}^{+} \mathrm{CD}_{11 \mathrm{c}^{+}}$cells as well as FITC $^{\mathrm{lo} / \mathrm{neg}}$ major histocompatibility complex class $\mathrm{II}^{+} \mathrm{CD} 11 \mathrm{c}^{+}$cells in the skindraining lymph nodes. Of importance, our studies did not identify a particular DC subset with altered migration capacity, but instead all migratory (CD8a-), BM-derived ( $>90 \%$ of CD45.1 donor origin in CD45.2 chimeric mice) dermal DC types had reduced ability. There were similarly fewer $\mathrm{CD}_{103^{+}}$and $\mathrm{CD} 103^{-} \mathrm{CD} 11 \mathrm{~b}^{\mathrm{int} / \mathrm{hi}}$ DCs in the skindraining lymph nodes of UV-chimeric mice 24 hours after FITC administration. A role for Langerhans cells in the reduced responses to FITC in UV-chimeric mice was excluded as they would not be CD45.1 $1^{+}$because of their origin from embryonic fetal liver monocytes. ${ }^{11}$ Further experimentation with mixed chimeras suggested a cellintrinsic effect and that the effect of UV radiation exposure on the DC progenitors in the BM was by nature epigenetic and unrelated to IL-10 production. ${ }^{9}$ An altered DC migratory capacity was not restricted to those engrafted into the skin of UV-chimeric mice; DCs in the respiratory tract of UV-chimeric mice (labeled by the dye PKH26 delivered intranasally) were similarly poor to migrate to draining lymph nodes after lipopolysaccharide activation. ${ }^{12}$

UVR-induced prostaglandin $\mathrm{E}_{2}\left(\mathrm{PGE}_{2}\right)$ has been implicated in the effects of UVR exposure on DC progenitors in the $\mathrm{BM}$, principally because the effect of UVR can be blocked by administration of the cyclooxygenase inhibitor, indomethacin, and can be replicated by s.c. delivery of $\mathrm{PGE}_{2}$ itself. $^{8}$

The basis of the reduced migration of DCs differentiating from the BM of UV-irradiated and UV-chimeric mice has not been determined. These DCs exhibit similar cytokine responses and surface marker expression to DCs derived from the BM of nonirradiated mice and control-chimeric mice. ${ }^{8,10}$ However, changes to flux through metabolic pathways as a determinant of their altered immune function had not been investigated. In this study, we show that DCs differentiating from the BM after UV irradiation of skin have an increased glycolytic profile, resulting in increased lactate production, and that increased expression of the enzyme 3-hydroxyanthranilate 3,4-dioxygenase (HAAO), contributes. Using an inhibitor of HAAO, we demonstrate an association between the glycolytic properties of DCs differentiating from the $\mathrm{BM}$ of $\mathrm{UV}$-irradiated mice and their migration abilities. This study suggests that after UV irradiation of skin, DC progenitor cells in the BM are imprinted with changes that alter the bioenergetics of their daughter cells and, in turn, their ability to respond by migration toward chemokines. Furthermore, UVR-induced $\mathrm{PGE}_{2}$ is implicated in the effects on cells in the bone marrow.

\section{Materials and Methods}

\section{Mice and Ethics Statement}

Female C57BL/6J (CD45.2 alloantigen) and B6.SJL-Ptprc ${ }^{\mathrm{a}}$ (CD45.1 alloantigen) mice were obtained from the Animal Resources Centre (Murdoch, WA, Australia). All experiments were performed with the approval of the Telethon Kids Institute (West Perth, WA, Australia) Animal Ethics Committee (approval numbers 236 and 278), and standard operating procedures for euthanasia and anesthesia were defined according to guidelines of the National Health and Medical Research Council of Australia.

\section{UV Irradiation of Mice}

A bank of TL40W/12RS lamps (Philips, Amsterdam, the Netherlands) emitting broadband UVR with $65 \%$ UVB $(280$ to $320 \mathrm{~nm})$ and peak emission at $313 \mathrm{~nm}$ was used. Twenty-four hours before irradiation, a uniform area of dorsal skin of mice was shaved $\left(8 \mathrm{~cm}^{2}\right)$. To administer UVR, mice were held in perspex compartments covered with 0.2 -mm polyvinyl chloride plastic to eliminate wavelengths $<290 \mathrm{~nm} .{ }^{13}$ The compartments were placed $20 \mathrm{~cm}$ beneath the UV lamps and $8 \mathrm{~kJ} / \mathrm{m}^{2}$ UVR was delivered; this amount of UVR is equivalent to three to four minimal erythemal doses. ${ }^{13}$ The UVB output by the lamps was measured using a UVX radiometer (Ultraviolet Products Inc., Upland, CA). Mice were 6 to 10 weeks old at the time of irradiation. Mice were UV irradiated 3 days before BM harvest.

\section{$\mathrm{PGE}_{2}$ Pellets and Preincubation of BM Cells with $\mathrm{dmPGE} 2$}

Mice were s.c. implanted with two $\mathrm{PGE}_{2}$ pellets, each containing $0.1 \mathrm{mg}$ with a constant release of $4.76 \mu \mathrm{g} / \mathrm{day}$ 
(total, $9.52 \mu \mathrm{g} /$ day; Innovative Research of America, Sarasota, FL), 3 days before isolation of BM cells. The pellets were inserted into the loose skin at the top of the back. ${ }^{8}$ Alternatively, freshly isolated BM cells from naïve mice were suspended in RPMI 1640 medium (HyClone; GE Health Care Life Sciences, Logan, UT) supplemented with $10 \%$ fetal calf serum (HyClone; RPMI-10) at $10^{7}$ cells $/ \mathrm{mL}$. As previously published for umbilical cord cell preparations, ${ }^{14}$ cell suspensions were pulsed for 2 hours at $37^{\circ} \mathrm{C}$ with $10 \mu \mathrm{mol} / \mathrm{L}$ 16-16-dimethyl prostaglandin $\mathrm{E}_{2}\left(\mathrm{dmPGE}_{2}\right.$; Sigma-Aldrich, St Louis, MO), prepared as per manufacturer's instructions. As a control, cells were incubated with an equivalent volume of RPMI-10 for 2 hours at $37^{\circ} \mathrm{C}$. Cells were washed before further assay.

\section{Culture of BM Cells for Differentiation of $\mathrm{CD}_{11 \mathrm{C}^{+}}$Cells}

As previously published, ${ }^{8-10}$ freshly isolated BM cells were cultured for 5 days in RPMI-10, as described above, $10 \mathrm{ng} /$ $\mathrm{mL}$ GM-CSF, and $10 \mathrm{ng} / \mathrm{mL}$ IL-4 (Peprotech Inc., Rocky Hill, NJ) at a density of $8 \times 10^{5}$ cells $/ \mathrm{mL}$ in 24 -well plates to promote $\mathrm{CD} 11 \mathrm{c}^{+}$cell differentiation (medium replaced on days 2 and 4). Nonadherent cells were enriched to $>95 \%$ $\mathrm{CD} 11 \mathrm{c}^{+}$cells (confirmed by flow cytometry) using antiCD11c magnetic microbeads (Miltenyi Biotec, Bergisch Gladbach, Germany) and autoMACS-Pro (Miltenyi Biotec) separation. Analysis of major histocompatibility complex class II expression and CD11b expression showed that after bead separation, the cells were approximately $50 \% \mathrm{CD} 11 \mathrm{~b}^{\text {hi }}$ and $\mathrm{CD} 11 \mathrm{~b}^{\text {lo }}{ }^{15}$ Where indicated, the CD11 $\mathrm{c}^{+}$cells were pulsed with $500 \mu \mathrm{mol} / \mathrm{L}$ 6-chloro-DL-tryptophan ${ }^{16}$ (ChemImpex International, Wood Dale, IL) for 30 minutes at $37^{\circ} \mathrm{C}$ before washing and further assay.

\section{Assays of Lactate Production and Glucose Use}

Concentrations of secreted L-lactate (subsequently called lactate) in culture supernatants were quantified using the Glycolysis Cell-Based Assay Kit (catalog number 600450; Cayman Chemical, Ann Arbor, MI). Briefly, enriched BMderived $\mathrm{CD} 11 \mathrm{c}^{+}$cells were cultured in U-bottom 96-well plates at a density of $0.8 \times 10^{6} / \mathrm{mL}$ in RPMI 1640 medium containing $0.5 \%$ fetal calf serum, $10 \mathrm{ng} / \mathrm{mL}$ GM$\mathrm{CSF}$, and $10 \mathrm{ng} / \mathrm{mL}$ IL-4. Supernatants were collected after 3, 8, 18, and 24 hours (separate wells were harvested for each time point). Supernatants were immediately centrifuged $(453 \times g, 5$ minutes) to ensure that they were cell free and then frozen at $-80^{\circ} \mathrm{C}$ for later analysis. Where indicated, glucose levels were quantified in culture supernatants using the Amplex Red Glucose/Glucose Oxidase Kit (catalog number A22189; Thermo Fisher, Waltham, MA). The standard glucose concentration in RPMI 1640 medium is $11.1 \mathrm{mmol} / \mathrm{L}$; the glucose used over 24 hours was calculated by subtracting the concentration at 24 hours from that at 0 hours.

\section{Bioenergetics Measurements}

Bioenergetics was measured using a Seahorse $\mathrm{XF}^{\mathrm{e}} 96$ Extracellular Flux Analyzer (Seahorse Bioscience, North Billerica, MA) and the Seahorse glycolytic and mitochondrial stress tests, as previously reported. ${ }^{17}$ The extracellular acidification (ECAR) and oxygen consumption rates (OCRs), along with the seeding density and reagents, were optimized according to the manufacturer's specification. In short, $1.6 \times 10^{5}$ cells/well were cultured in RPMI-10 supplemented with GM-CSF and IL-4 for 24 hours in poly-D-lysine-coated (Sigma-Aldrich) culture microplates (Seahorse Bioscience), and spun at $201 \times g$ to ensure adherence. After 24 hours, the medium was replaced with either serum-free, Dulbecco's modified Eagle's medium base medium $(1 \mathrm{mmol} / \mathrm{L}$ sodium pyruvate, $2 \mathrm{mmol} / \mathrm{L}$ glutamine, and $0 \mathrm{mmol} / \mathrm{L}$ glucose) for the glycolytic stress test or serum-free Dulbecco's modified Eagle's medium assay medium $(1 \mathrm{mmol} / \mathrm{L}$ sodium pyruvate, $2 \mathrm{mmol} / \mathrm{L}$ glutamine, and $2.5 \mathrm{mmol} / \mathrm{L}$ glucose) for the mitochondrial stress test. Glycolytic and mitochondrial parameters were determined using the following injection strategy, all at final concentration: glycolytic stress test, $25 \mathrm{mmol} / \mathrm{L}$ glucose, $1 \mu \mathrm{mol} / \mathrm{L}$ oligomycin, and $100 \mathrm{mmol} / \mathrm{L}$ 2-deoxyglucose; mitochondrial stress test, $1 \mu \mathrm{mol} / \mathrm{L}$ oligomycin, $1 \mu \mathrm{mol} / \mathrm{L}$ carbonyl cyanide-4-phenylhydrazone, $100 \mathrm{nmol} / \mathrm{L}$ rotenone, and $1 \mu \mathrm{mol} / \mathrm{L}$ antimycin $\mathrm{A}$ in combination. Three measurements were taken after each drug addition (6 minutes apart); the last measurement before subsequent injection was used for the statistical calculations. Results (both ECAR and OCR) were normalized according to protein levels in each well using radioimmunoprecipitation assay buffer and the bicinchoninic acid protein assay (Thermo Fisher).

\section{Bioenergetic Data Analysis}

Data were analyzed as published previously. ${ }^{18}$ The addition of $25 \mathrm{mmol} / \mathrm{L}$ glucose and a corresponding increase in ECAR was used to determine stimulated glycolysis. Oligomycin $(1 \mu \mathrm{mol} / \mathrm{L})$ was then added, and the difference between this ECAR reading and baseline ECAR was defined as the glycolytic capacity. The difference between the glycolytic capacity and stimulated glycolysis was defined as the glycolytic reserve. Finally, 2-deoxyglucose was added to estimate non-glucosederived ECAR. For the mitochondrial stress test, the initial OCR (pmol $\mathrm{O}_{2} /$ minute per $\mu \mathrm{g}$ protein) was measured, represented the resting energetics of the cells in $2.5 \mathrm{mmol} / \mathrm{L}$ glucose, and included both the OCR due to mitochondrial activity (termed basal respiration) and non-mitochondrial-derived OCR. The latter element was precisely determined using rotenone and antimycin A. Subtraction of this value from the initial resting OCR reveals the basal respiration. Similarly, subtraction of the OCR under the action of oligomycin from the initial resting OCR produces the OCR that is coupled to ATP synthesis. Furthermore, subtraction of the ATP-coupled OCR from the basal respiration calculated above provides the 
OCR associated with proton leak. Carbonyl cyanide-4phenylhydrazone was used to determine the maximum respiration rate, which was calculated by subtracting the nonmitochondrial OCR from the maximum OCR recorded during carbonyl cyanide-4-phenylhydrazone administration. The reserve capacity was the difference between the maximum and basal respiration rates. All OCR and ECAR initial measurements were standardized to $100 \%$, and all subsequent changes in OCR/ECAR were also calculated as a percentage change relative to $100 \%$.

\section{Microarray of $\mathrm{CD}_{11 \mathrm{c}^{+}}$Cells}

Total RNA was extracted from triplicate preparations of BMdifferentiated $\mathrm{CD} 11 \mathrm{c}^{+}$cells using TRIzol (Life Technologies, Carlsbad, CA), followed by an RNeasy plus mini kit (Qiagen, Hilden, Germany), according to the manufacturer's instructions. At least $500 \mathrm{ng}$ at $50 \mathrm{ng} / \mathrm{mL}$ (evaluated by the absorbance 260/280 ratio using a NanoDrop ND 1000 spectrophotometer; NanoDrop Technologies, Wilmington, DE) was sent to the Ramaciotti Centre, University of New South Wales, for analysis using Affymetrix GeneChip Mouse Gene 1.0 ST Array (Thermo Fisher). The oligo package ${ }^{16,19}$ was used to read the Affymetrix CEL files into R (http:// www.R-project.org; last accessed March 31, 2017) and to preprocess the arrays using the robust multichip average method. Quality control of the arrays was performed using the arrayQualityMetrics package. ${ }^{20}$ The limma package $^{21}$ was used to conduct differential expression analysis, with $P$ values adjusted for multiple testing using the method of Benjamini and Hochberg. ${ }^{22}$ To generate a hypothesis for significant molecules differentially expressed by $\mathrm{CD} 11 \mathrm{c}^{+}$ cells, a molecular interaction network was generated using prior knowledge from the Ingenuity Systems Knowledge Base (Ingenuity Systems, Redwood City, CA). The raw CEL files and processed data are available from National Center for Biotechnology Information Gene Expression Omnibus (https://www.ncbi.nlm.nih.gov/geo; accession number GSE74468).

\section{RT-qPCR}

Two genes were validated using quantitative RT-PCR (RT-qPCR). Reverse transcription was performed using the Quantitect Reverse Transcription Kit (Qiagen). Real-time PCR primers were obtained from Qiagen (QuantiTect catalog number QT00258398 for HAAO and catalog number QT00103502 for lactate dehydrogenase $C$ ). The primers for the housekeeping gene, $\beta$-actin, were obtained from Sigma-Aldrich. Quantitect SYBR Green was used for qPCR on the AB17900HT instrument. Fold change was determined by using the $2^{\Delta \Delta \mathrm{Ct}}$ method.

\section{Assay of DC Migration toward Chemokine CCL21}

BM-differentiated, bead-purified DCs $\left(2.5 \times 10^{5}\right)$ were seeded into transwell inserts with $8 \mu \mathrm{mol} / \mathrm{L}$ pores (Falcon
353097; BD Biosciences, Franklin Lakes, NJ) in RPMI 1640 medium supplemented with $10 \%$ fetal calf serum, GM-CSF, and IL-4, as described above. The inserts were placed into a 24-well companion plate with the same medium containing $250 \mathrm{ng} / \mathrm{mL}$ chemokine (C-C motif) ligand (CCL)-21 (R\&D Systems, Minneapolis, MN). ${ }^{23}$ The cells were allowed to migrate for 4 hours before fixation of the filters in $4 \%$ paraformaldehyde. Migrated cells (on the underside of the insert) were stained with NucBlue Fixed ReadyProbes (Thermo Fisher), as per manufacturer's instructions, and imaged on a Nikon C2plus confocal microscope (Nikon, Minato, Japan). Ten representative fields of view per filter were collected at $\times 20$ magnification.

\section{Generating Chimeric Mice}

Control- and UV-chimeric mice were generated as previously described. ${ }^{9,12}$ In short, 8-week-old C57BL/6J mice (recipients, CD45.2 alloantigen) were $\gamma$-irradiated $(2 \times 550 \mathrm{rad})$ using a ${ }^{137} \mathrm{Cs}$ source (Gammacell 3000 Elan; MDS Nordion, Ottawa, ON, Canada) before injection of $2 \times 10^{6} \mathrm{BM}$ cells from congenic B6.SJL-Ptprc ${ }^{\mathrm{a}}$ (CD45.1 alloantigen) mice that had been UV irradiated $\left(8 \mathrm{~kJ} / \mathrm{m}^{2}\right) 3$ days previously. Control chimeric mice were $\gamma$-irradiated and injected with $2 \times 10^{6} \mathrm{BM}$ cells from naïve congenic B6.SJL-Ptprc ${ }^{a}$ mice (shaved but not UV irradiated). The engraftment of cells in the chimeric mice was tracked, as previously published, at 16 weeks after reconstitution. ${ }^{9,12}$ Cells were confirmed to be $>95 \%$ CD45.1 (ie, of donor origin). dmPGE $2^{-}$and their controlchimeric mice were generated using an identical approach; $2 \times 10^{6} \mathrm{BM}$ cells pulsed with $\mathrm{dmPGE}_{2}$ for 2 hours at $37^{\circ} \mathrm{C}$, or control medium, were injected into $\gamma$-irradiated recipient mice.

\section{Assay of Priming Ability of $\mathrm{CD}_{11 \mathrm{c}^{+} \text {Cells }}$}

Enriched CD11c $\mathrm{c}^{+}$cells $(>90 \%)$ at $10^{6}$ cells $/ \mathrm{mL}$ in RPMI-10 were pulsed with $1 \mathrm{mmol} / \mathrm{L}$ 2,4-dinitrobenzene sulfonic acid sodium salt (MP Biomedicals LLC, Solon, OH) for 30 minutes at $37^{\circ} \mathrm{C}$ before washing and resuspension at $5 \times$ $10^{7}$ cells $/ \mathrm{mL}$ in $0.9 \%$ saline, and $10^{6}$ cells were injected into the ear pinnae of naïve C57BL6/J mice $(n=8$ ears per group). After 7 days, each side of the ears was painted with $10 \mu \mathrm{L} \mathrm{0.2 \%} \mathrm{2,4-dinitro-1-fluorobenzene} \mathrm{(Sigma-Aldrich)} \mathrm{in}$ acetone/olive oil (4:1); 2,4-dinitro-1-fluorobenzene is the nonwater soluble form of 2,4-dinitrobenzene sulfonic acid sodium salt, but with the same antigenic moiety as 2,4-dinitrobenzene sulfonic acid sodium salt. ${ }^{8-10}$ Ear thicknesses were determined before and 24 hours after challenge with 2,4-dinitro-1-fluorobenzene using a springloaded micrometer (Mitutoyo, Aurora, IL). The ear thickness before painting was subtracted from that measured after 24 hours. 

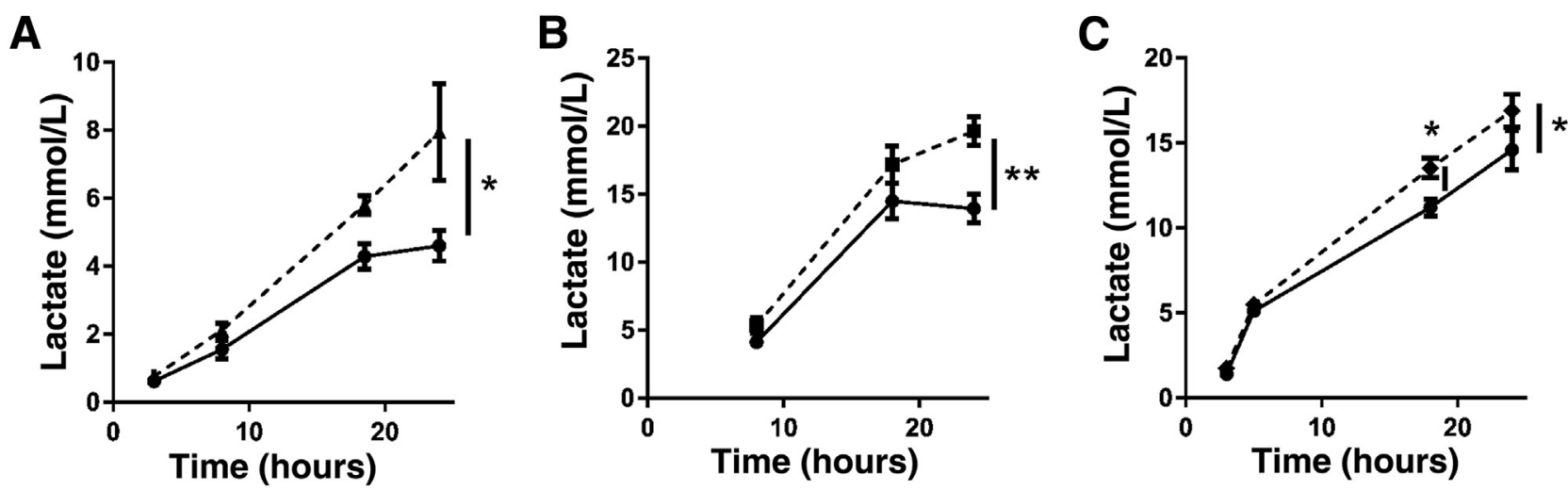

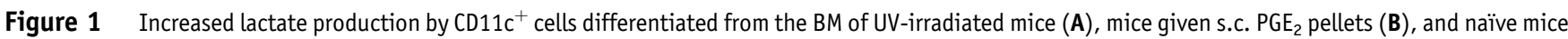
pulsed in vitro for 2 hours with $\mathrm{dmPGE}_{2}$ (C). A: BM cells were isolated from nonirradiated mice (circles, solid line), and mice irradiated with UVR 3 days previously (triangles, dashed line), and cultured for 5 days with GM-CSF and IL-4. B: BM cells were isolated 3 days after mice were given s.c. placebo pellets (circles, solid line), or administered PGE ${ }_{2}$-releasing pellets (squares, dashed line), and cultured for 5 days with GM-CSF and IL-4. C: BM cells were pulsed with dmPGE 2 (diamonds, dashed line) or RPMI-10 (control; squares, solid line) at $37^{\circ} \mathrm{C}$ for 2 hours before culture for DC differentiation. A-C: CD11c cells were purified from the BM cell cultures and incubated as triplicate wells for each time point in medium containing $0.5 \%$ fetal calf serum. Cell-free supernatants were harvested at multiple times over 24 hours. Lactate levels in the supernatants were measured; a mean value for cells from individual mice, and then a mean value of the means for all mice in the group, was calculated. Data are expressed as means \pm SEM $(\mathbf{A}-\mathbf{C}) . n=6(\mathbf{A}$, nonirradiated and irradiated mice); $n=3$ (B, mice given placebo and mice given $\left.\mathrm{PGE}_{2}\right) ; n=4$ (C, BM cells pulsed with $\mathrm{dmPGE} \mathrm{E}_{2}$ or RPMI-10). ${ }^{*} P<0.05,{ }^{*} P<0.01$ for differences between cells from the control mice and those from the UVirradiated, $\mathrm{PGE}_{2}$-administered mice, or bone marrow cells pulsed with $\mathrm{dmPGE}_{2}$ in vitro.

\section{Assay of $\mathrm{CD}_{11 \mathrm{c}^{+}}$Cell Migration into the Peritoneal Cavity}

The migration capabilities of $\mathrm{CD} 11 \mathrm{c}^{+}$cells into the peritoneal cavity of the UV-chimeric mice were examined by i.p. injection of $1 \mathrm{~mL}$ thioglycollate (3.8\% Medium Brewer Modified; BD Bioscience). After 3 days, the peritoneal cavity was washed out with saline. The harvested cells were counted and identified by staining as $\mathrm{CD} 11 \mathrm{c}^{+} \mathrm{F} 4 / 80^{-} \cdot{ }^{24}$ The expression of the chemokine receptors CCR2 and CCR7 was examined.

\section{Results}

Increased Lactate Production by $\mathrm{CD} 11 \mathrm{c}^{+}$Cells Differentiated from the BM of UV-Irradiated Mice

With no phenotype identified until now, we hypothesized that changes to the flux through metabolic pathways may be responsible for the reduced immunogenicity of DCs differentiating from the BM of UV-irradiated mice. Our first analysis was of lactate production, an easily measured product of glycolysis, by $\mathrm{CD} 11 \mathrm{c}^{+}$cells incubated for 24 hours in medium containing $0.5 \%$ fetal calf serum. Lactate levels were significantly increased after 18 and 24 hours in the supernatants of $\mathrm{CD} 11 \mathrm{c}^{+}$cells differentiated from the BM of UV-irradiated mice (Figure 1). The different rates of lactate produced suggested that there were absolute differences in lactate production, rather than different kinetics for production of similar amounts. Glucose use was also measured in the supernatants of $\mathrm{CD} 11 \mathrm{c}^{+}$cells from the BM of three nonirradiated mice, and three UV-irradiated mice, and correlated with increased lactate production by these same cells (Table 1).
Increased Lactate Production by $\mathrm{CD}_{11 \mathrm{C}}{ }^{+}$Cells Differentiated from the BM of Mice Administered S.C.

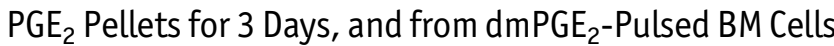

Previous experimentation has suggested that UVR-induced $\mathrm{PGE}_{2}$ is responsible for altered priming abilities of DCs differentiating from the $\mathrm{BM}$ of UV-irradiated mice. ${ }^{8}$ Accordingly, lactate production by $\mathrm{CD} 11 \mathrm{c}^{+}$cells differentiated from the $\mathrm{BM}$ of mice exposed for 3 days to s.c. $\mathrm{PGE}_{2}$ or placebo pellets was investigated. The cells differentiated from the $\mathrm{BM}$ of mice treated with s.c. $\mathrm{PGE}_{2}$ pellets produced significantly greater levels of lactate than the cells differentiated from the BM of mice given placebo pellets (Figure 1B). Lactate production by $\mathrm{CD} 11 \mathrm{c}^{+}$cells differentiated from $\mathrm{BM}$ cells pulsed with $\mathrm{dmPGE}_{2}$ for 2 hours was also significantly increased (Figure 1C).

Increased Aerobic Glycolytic Profile of CD11c ${ }^{+}$Cells Differentiated from the BM of UV-Irradiated Mice

To gain more insight into changes in the glycolytic pathway, we next performed a glycolytic stress test using a Seahorse Extracellular Flux Analyser (Agilent, Santa Clara, CA) on $\mathrm{CD} 11 \mathrm{c}^{+}$cells differentiated from the BM of UV-irradiated mice. There were no significant differences in baseline ECAR for $\mathrm{CD}_{11 \mathrm{c}^{+}}$cells differentiated from the $\mathrm{BM}$ of nonirradiated (control) and from UV-irradiated mice (mean baseline ECAR for all cell preparations of approximately 4 milli-pH units/minute per $\mu \mathrm{g}$ total protein). For both experiments (Exp 1 and $\operatorname{Exp} 2$ ), the ECAR measures were standardized to baseline levels. When stimulated with $25 \mathrm{mmol} / \mathrm{L}$ glucose, there was significantly increased glycolysis for $\mathrm{CD} 11 \mathrm{c}^{+}$cells differentiated from the BM of 
Table 1 Glucose Consumed, and Lactate Produced, after 24 Hours by CD11c ${ }^{+}$Cells Cultured in $0.5 \%$ Serum-Containing Medium for 24 Hours

\begin{tabular}{llllll}
\hline Glucose consumed $(\mu \mathrm{mol} /$ well $)$ & & & Lactate produced $(\mu \mathrm{mol} / \mathrm{L})$ \\
\cline { 2 - 5 } $\begin{array}{lllll}\text { Cells from BM of } \\
\text { nonirradiated mice }\end{array}$ & $\begin{array}{l}\text { Cells from BM of } \\
\text { UV-irradiated mice }\end{array}$ & & & $\begin{array}{l}\text { Cells from BM of } \\
\text { nonirradiated mice }\end{array}$ & Cells from BM of \\
\hline $0.08 \pm 0.04$ & $0.21 \pm 0.02^{*}$ & & $4.31 \pm 0.38$ & UV-irradiated mice \\
\hline
\end{tabular}

For each group, the means \pm SEM for three cell populations differentiated from the BM of three individual mice is shown.

${ }^{*} P<0.05$.

BM, bone marrow.

UV-irradiated mice compared with the increase for cells from nonirradiated mice (Figure 2). After the addition of oligomycin, there were further increases in ECAR (glycolytic reserve) and there was a significantly greater increase for cells from the BM of UV-irradiated mice in Exp 1. The glycolytic capacity (summation of increased ECAR in response to added glucose and then oligomycin) was significantly increased for cells from the BM of UV-irradiated mice in both experiments (Figure 2). The significantly increased glycolysis and glycolytic capacity measured in the cells differentiated from the BM of $\mathrm{UV}$-irradiated mice is consistent with the increased lactate measured in the supernatants of CD11 ${ }^{+}$cells differentiated from the BM of UV-irradiated mice (Figure 1A).

No Significant Difference in Responses to a Mitochondrial Stress Test by CD11c $\mathrm{c}^{+}$Cells Differentiated from the BM of Nonirradiated and UV-Irradiated Mice

We next examined the responses to a mitochondrial stress test to determine whether the enhanced glycolytic response was due to reduced oxidative phosphorylation. The responses by cells differentiated from the BM of nonirradiated
A
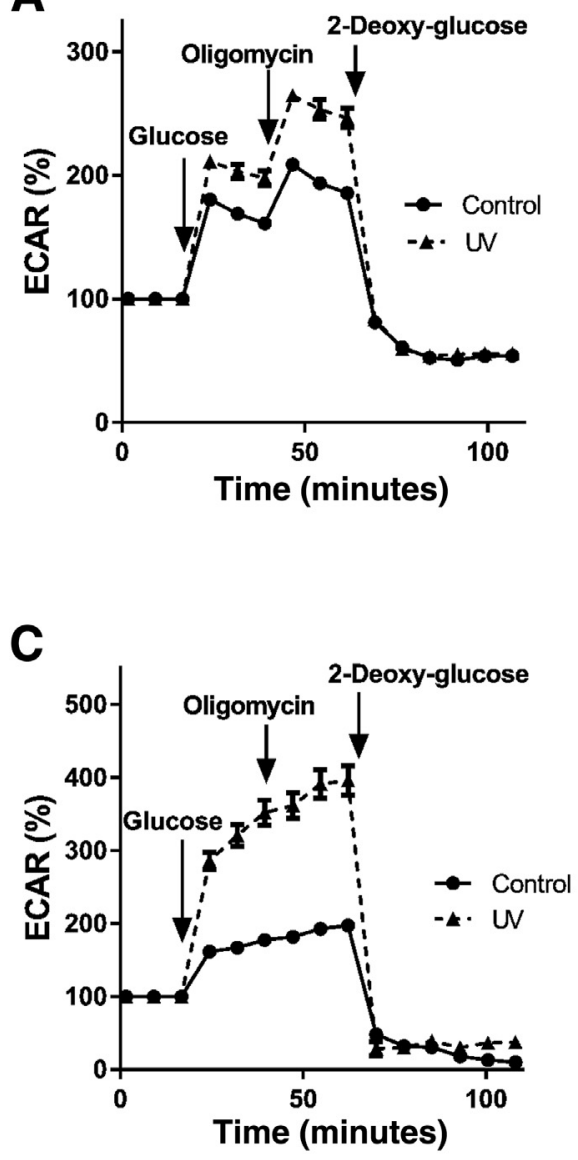

B
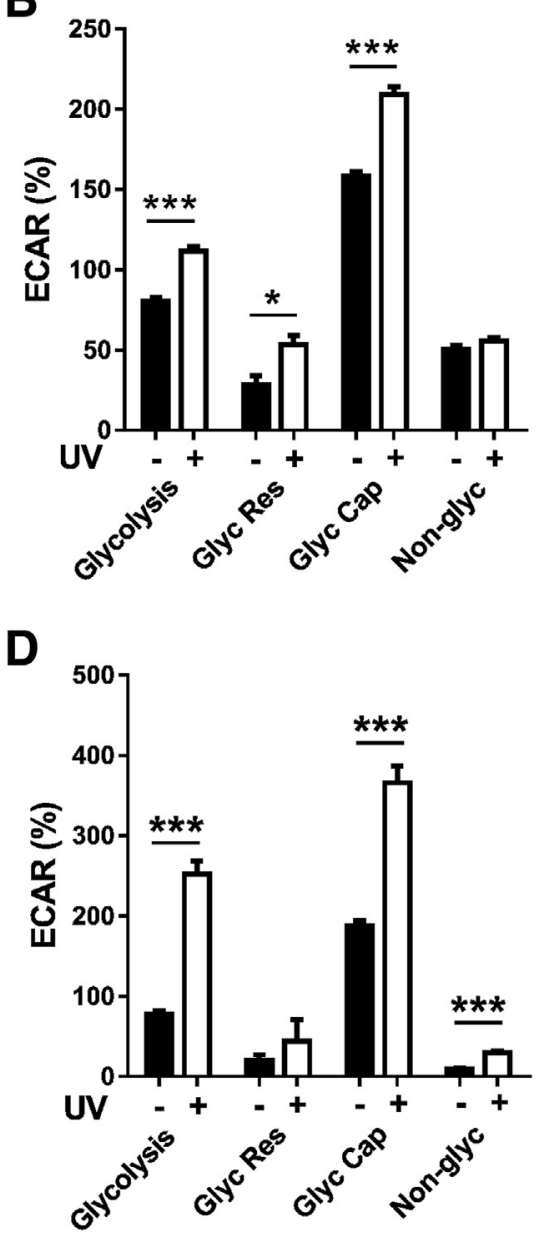

Figure 2 Increased glycolysis and glycolytic capacity (Glyc Cap) of CD11c ${ }^{+}$cells differentiated from the BM of UV-irradiated mice. In two separate experiments (experiment 1 shown in $\mathbf{A}$ and $\mathbf{B}$, experiment 2 shown in $\mathbf{C}$ and $\mathbf{D}$ ), BM cells were isolated from a nonirradiated mouse (circles, solid line), and a mouse irradiated with UVR 3 days previously (triangles, dashed line), and cultured for 5 days with GM-CSF and IL-4. CD11c cells ( $>90 \%$ enriched) were centrifuged onto poly-Dlysine-coated wells, and incubated for a further 24 hours in RPMI-10 with GM-CSF and IL-4. Cells were then resuspended in serum-free, glucose-free base medium and the ECAR was measured after sequential addition of $25 \mathrm{mmol} / \mathrm{L}$ glucose, $1 \mu \mathrm{mol} / \mathrm{L}$ oligomycin, and $100 \mathrm{mmol} / \mathrm{L}$ 2-deoxyglucose to determine the response to the glycolytic stress test. After protein normalization, ECAR measurements were standardized according to the initial baseline ECAR readings, and the relative change in ECAR after addition of glycolytic modulators was calculated as a percentage change relative to the initial ECAR. The results of $\mathbf{B}$ have been calculated from the results of $\mathbf{A}$ for $\operatorname{Exp} 1$. The results of $\mathbf{D}$ have been calculated from the results of $\mathbf{C}$ for $\operatorname{Exp} 2$. Data are expressed as means \pm SEM. $n=4$ replicate wells (A and $\mathbf{B}) ; n=11$ replicate wells (C and D). ${ }^{*} P<0.05,{ }^{* * *} P<0.001$. Glyc Res, glycolytic reserve; Non-glyc, nonglycolytic. 
(control) and UV-irradiated mice in the two independent experiments were similar (Figure 3). There was only a slight, but significant, decrease in maximum respiratory capacity for cells from UV-irradiated mice in Exp 1, but this was not maintained in Exp 2.

\section{Differentially Expressed Genes in CD11c ${ }^{+}$Cells Differentiated from the BM of UV-Irradiated Mice}

To better understand the basis for greater glycolysis by $\mathrm{CD} 11 \mathrm{c}^{+}$cells differentiating from the BM of UV-irradiated mice, differential gene expression analysis was conducted in $\mathrm{CD} 11 \mathrm{c}^{+}$cells differentiated from the BM of each of the three nonirradiated mice, and three mice exposed to UVR $\left(8 \mathrm{~kJ} / \mathrm{m}^{2}\right), 3$ days previously. After adjustment for multiple testing, 25 probes were found to be differentially expressed between cells from the UV-irradiated and nonirradiated mice (Benjamini-Hochberg-adjusted $P \leq 0.05$ ) (Table 2). When transcripts for genes coding enzymes traditionally associated in macrophages with carbohydrate, ketone body, fatty acid, and amino acid metabolism ${ }^{25}$ were analyzed in $\mathrm{CD} 11 \mathrm{c}^{+}$cells differentiated from $\mathrm{BM}$ of UV-irradiated mice, four enzymes had an unadjusted $P<0.1$ (Table 3).
Identification of Functional Pathways Associated with the Differentially Expressed Genes in CD11c ${ }^{+}$Cells Differentiated from the BM of UV-Irradiated Mice

To provide some insight into the regulation of the differentially expressed genes identified above, we used the 25 gene probes as input to the Ingenuity Systems Knowledge base of functional molecular interaction data derived from previous studies and performed canonical pathway analysis. $^{22}$ Of the genes and pathways that may associate with increased glycolytic capacity of CD11 $\mathrm{c}^{+}$cells differentiated from the $\mathrm{BM}$ of UV-irradiated mice, the pathway involving HAAO was significant among the 26 pathways identified (Table 4).

\section{Validation of Differentially Expressed Genes by RT-qPCR}

We sought to validate the increased expression of the enzyme, HAAO, as well as that of lactate dehydrogenase C, an enzyme whose expression did not show statistical significance in the differential expression analysis (Table 3), but may be related to increased lactate production. The
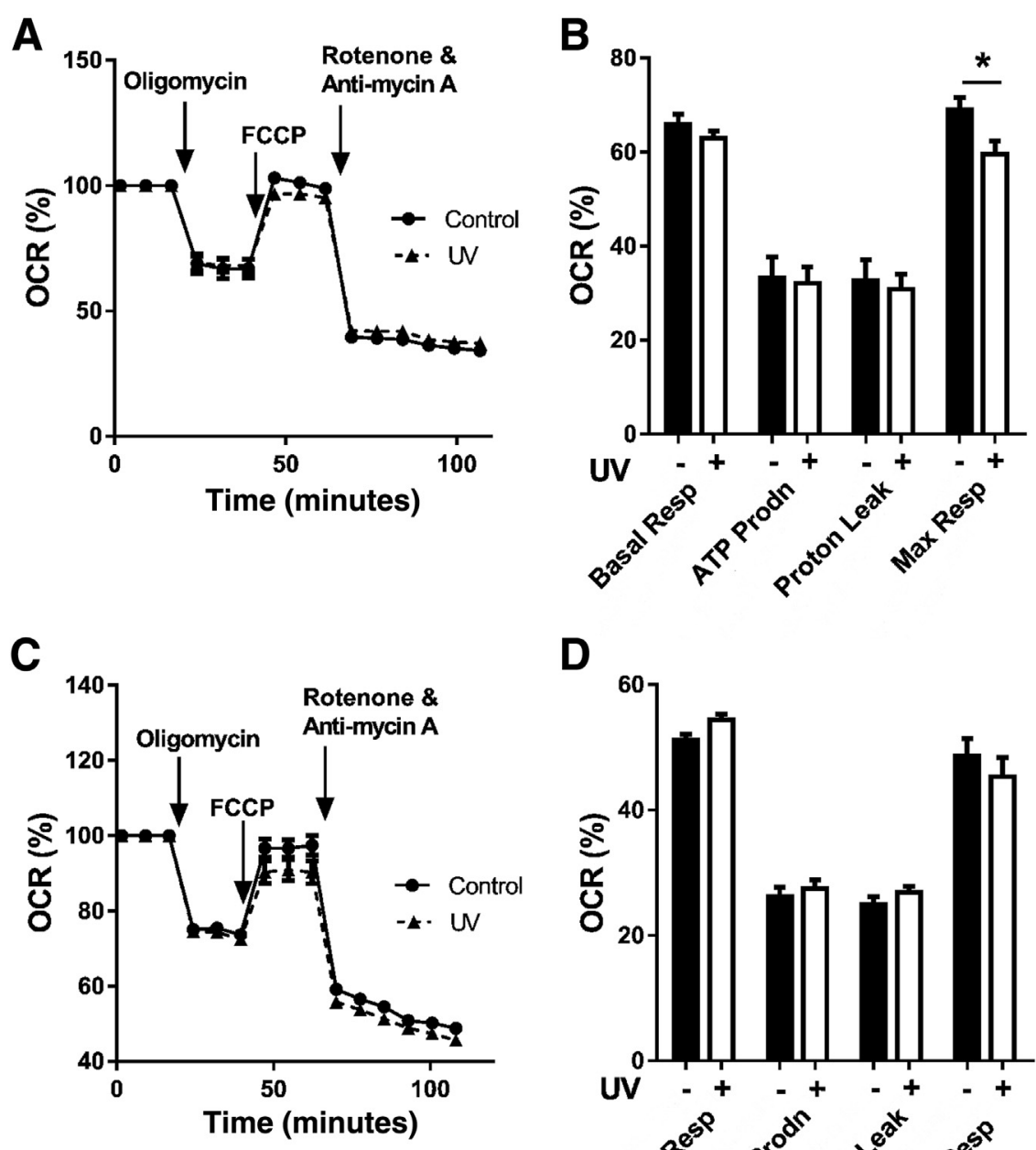

Figure 3 No significant difference was found in the mitochondrial stress test by $\mathrm{CD}_{11} \mathrm{c}^{+}$cells differentiated from the BM of UV-irradiated mice. $\mathrm{BM}$-derived $\mathrm{CD} 11 \mathrm{C}^{+}$cells were obtained, centrifuged onto poly-o-lysine-coated wells, and cultured for a further 24 hours in RPMI-10 with GM-CSF and IL-4. The medium was replaced with assay serum-free medium containing $2.5 \mathrm{mmol} / \mathrm{L}$ glucose. The OCR was measured after sequential addition of $1 \mu \mathrm{mol} / \mathrm{L}$ oligomycin, $1 \mu \mathrm{mol} / \mathrm{L}$ carbonyl cyanide-4-phenylhydrazone (FCCP), and $100 \mathrm{nmol} / \mathrm{L}$ rotenone and $1 \mu \mathrm{mol} / \mathrm{L}$ anti-mycin $\mathrm{A}$ in combination, to determine the response of cells to the mitochondrial stress test. After protein normalization, OCR measures were standardized to the initial baseline OCR readings, and the relative change in OCR after addition of mitochondrial modulators was calculated as a percentage change relative to the initial OCR. The results of $\mathbf{B}$ have been calculated from the results of $\mathbf{A}$ for experiment 1. The results of $\mathbf{D}$ have been calculated from the results of $\mathbf{C}$ for experiment 2. Cells differentiated from the BM of nonirradiated mice are shown by circles and a solid line, and those differentiated from the BM of mice irradiated with UVR are shown by triangles and a broken line. Data are expressed as means \pm SEM. $n=4$ replicate wells $(\mathbf{A}$ and $\mathbf{B})$; $n=11$ replicate wells $(\mathbf{C}$ and $\mathbf{D}) .{ }^{*} P<0.05$. ATP Prodn, ATP production; Basal Resp, basal respiration; Max Resp, maximum respiratory capacity. 


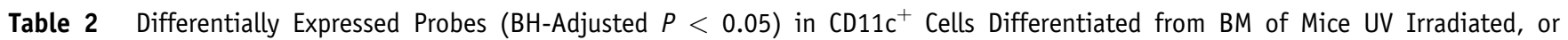
Nonirradiated, 3 Days before BM Harvest

\begin{tabular}{|c|c|c|c|c|c|c|}
\hline Probe ID & $\begin{array}{l}\log _{2} \text { fold } \\
\text { change }\end{array}$ & $\begin{array}{l}\text { Probe mean } \\
\text { expression }\end{array}$ & $P$ value & $\begin{array}{l}\text { Adjusted } \\
P \text { value }\end{array}$ & $\begin{array}{l}\text { Gene } \\
\text { symbol }\end{array}$ & Gene description \\
\hline 10345752 & 0.76924 & 11.06759 & $<0.0001$ & 0.0236 & Il1r2 & IL-1 receptor, type II \\
\hline 10469255 & 0.640574 & 8.180147 & $<0.0001$ & 0.0236 & Prkcq & Protein kinase $\mathrm{C}, \theta$ \\
\hline 10498367 & 0.697746 & 8.022949 & $<0.0001$ & 0.0236 & P2ry13 & Purinergic receptor P2Y, G-protein coupled 13 \\
\hline 10517508 & 0.634477 & 8.708724 & $<0.0001$ & 0.0236 & $C 1 q b$ & Complement component $1, \mathrm{q}$ subcomponent, $\beta$ polypeptide \\
\hline 10558769 & 0.735227 & 11.88327 & $<0.0001$ & 0.0236 & Ifitm1 & Interferon-induced transmembrane protein 1 \\
\hline 10576784 & 0.591101 & 10.19637 & $<0.0001$ & 0.0236 & $C d 209 a$ & CD209a antigen \\
\hline 10589703 & 0.540942 & 8.185172 & $<0.0001$ & 0.0236 & Ltf & Lactotransferrin \\
\hline 10597420 & 0.48783 & 6.894184 & $<0.0001$ & 0.0236 & Ccr4 & Chemokine ( $\mathrm{C}-\mathrm{C}$ motif) receptor 4 \\
\hline 10443869 & 0.498699 & 10.61106 & $<0.0001$ & 0.0318 & Cyp $4 f 16$ & Cytochrome P450, family 4, subfamily f, polypeptide 16 \\
\hline 10389654 & 0.404903 & 6.397659 & $<0.0001$ & 0.0397 & Epx & Eosinophil peroxidase \\
\hline 10394068 & 0.766653 & 10.30035 & $<0.0001$ & 0.0397 & Sectm1a & Secreted and transmembrane $1 \mathrm{~A}$ \\
\hline 10466224 & 1.092379 & 7.648954 & $<0.0001$ & 0.0397 & Ms4a3 & Membrane-spanning 4-domains, subfamily A, member 3 \\
\hline 10469278 & 0.573046 & 9.214686 & $<0.0001$ & 0.0397 & Il2ra & IL-2 receptor, $\alpha$ chain \\
\hline 10472916 & 0.647581 & 8.919741 & $<0.0001$ & 0.0397 & Cdca7 & Cell division cycle associated 7 \\
\hline 10569020 & 0.591459 & 8.472212 & $<0.0001$ & 0.0397 & Ifitm6 & Interferon-induced transmembrane protein 6 \\
\hline 10584841 & 0.454394 & 10.70426 & $<0.0001$ & 0.0397 & Amica1 & Adhesion molecule, interacts with CXADR antigen 1 \\
\hline 10587023 & 0.612678 & 9.101271 & $<0.0001$ & 0.0397 & $R a b 27 a$ & RAB27A, member RAS oncogene family \\
\hline 10576799 & 0.75318 & 8.135532 & $<0.0001$ & 0.0481 & Cd209e & CD209e antigen \\
\hline
\end{tabular}

$\mathrm{BH}$, Benjamini-Hochberg correction; BM, bone marrow.

validation was performed on RNA extracted from newly prepared preparations of $\mathrm{CD} 11 \mathrm{c}^{+}$cells from the $\mathrm{BM}$ of nonirradiated and UV-irradiated mice. As with the array, the expression of HAAO was significantly increased in cells differentiated from the BM of UV-irradiated mice $(P=0.025, n=6)$ (Figure 4). However, as also shown by the microarrays (Table 3), the expression of lactate dehydrogenase $\mathrm{C}$ was not significantly increased (Figure 4).

\section{Reduced Migration toward CCL21 by DCs Differentiated from the BM of UV-Irradiated Mice}

Alterations to cell function were still not linked with the metabolic changes in DCs differentiated from the BM of UV-irradiated mice. To prime a new immune response, DCs must migrate efficiently to lymph nodes, in large part controlled by CCL21 chemokine gradients. ${ }^{23}$ Thus, an in vitro assay of cell migration was established, and glycolytic flux, HAAO activity, and DC migration were investigated. $\mathrm{CD} 11 \mathrm{c}^{+}$cells that differentiated from the BM of UV-irradiated mice migrated significantly more slowly toward CCL21 in modified Boyden chambers (Figure 5A). There were no differences in the expression of CCR7, the receptor for CCL21, on CD11 $\mathrm{c}^{+}$cells that could explain the different migration measures (Figure 5B). If the CD11 $\mathrm{c}^{+}$ cells were preincubated for 30 minutes with an inhibitor of HAAO, 6-chloro-DL-tryptophan $(500 \mu \mathrm{mol} / \mathrm{L})$, differences in migration toward CCL21 were lost (Figure 5A), as were differences in lactate production by DCs from UV-irradiated and UV-nonirradiated mice (Figure $5 \mathrm{C}$ ).

The effect of preincubation with 6-chloro-DL-tryptophan on lactate production by DCs differentiated from BM cells pulsed

Table 3 Expression of Four Probes Targeting Genes Encoding Enzymes Associated with Carbohydrate, Ketone Body, Fatty Acid, and Amino Acid Metabolism

\begin{tabular}{lclllll}
\hline Probe ID & $\log _{2}$ fold change & $\begin{array}{l}\text { Probe mean } \\
\text { expression }\end{array}$ & $P$ value & $\begin{array}{l}\text { Adjusted } \\
P \text { value }\end{array}$ & Gene symbol & Gene description \\
\hline 10553309 & 0.308996 & 6.88648 & 0.0224 & 0.2879 & Ldhc & Lactate dehydrogenase C \\
10507824 & -0.12138 & 8.053829 & 0.0456 & 0.3552 & Oxct2b & 3-0xoacid CoA transferase 2B \\
10520612 & 0.139023 & 8.772316 & 0.0583 & 0.3837 & $K h k$ & Ketohexokinase \\
10581865 & -0.11078 & 7.178704 & 0.0787 & 0.4219 & Ldhd & Lactate dehydrogenase D \\
\hline
\end{tabular}


Table 4 Ingenuity Pathway Analysis of the 25 Probes Reported in Table 2 (BH-Adjusted $P<0.05$ )

\begin{tabular}{|c|c|c|c|}
\hline Ingenuity canonical pathways & $\begin{array}{l}-\log \\
(P \text { value })\end{array}$ & Ratio & Molecules \\
\hline Granulocyte adhesion and diapedesis & 2.94 & 0.0169 & SELP, SELL, IL1R2 \\
\hline iCOS-iCOSL signaling in T-helper cells & 2.15 & 0.0185 & PRKCQ, IL2RA \\
\hline Gai signaling & 2.06 & 0.0167 & P2RY13, CCR4 \\
\hline LXR/RXR activation & 2.05 & 0.0165 & S100A8, IL1R2 \\
\hline Atherosclerosis signaling & 2.03 & 0.0161 & S100A8, SELP \\
\hline Tryptophan degradation to 2-amino-3-carboxymuconate semialdehyde & 2.03 & 0.125 & HAAO \\
\hline Role of pattern recognition receptors in recognition of bacteria and viruses & 2.01 & 0.0157 & PRKCQ, C1QB \\
\hline IL-12 signaling and production in macrophages & 1.96 & 0.0148 & S100A8, PRKCQ \\
\hline Role of IL-17A in psoriasis & 1.82 & 0.0769 & S100A8 \\
\hline Hepatic cholestasis & 1.81 & 0.0123 & PRKCQ，IL1R2 \\
\hline NAD biosynthesis II (from tryptophan) & 1.76 & 0.0667 & HAAO \\
\hline$N F-\kappa B$ signaling & 1.75 & 0.0116 & PRKCQ，IL1R2 \\
\hline Production of nitric oxide and reactive oxygen species in macrophages & 1.72 & 0.0111 & S100A8, PRKCQ \\
\hline Clathrin-mediated endocytosis signaling & 1.70 & 0.0108 & S100A8, FGF23 \\
\hline Agranulocyte adhesion and diapedesis & 1.68 & 0.0106 & SELP, SELL \\
\hline Tryptophan degradation III (eukaryotic) & 1.63 & 0.05 & HAAO \\
\hline CAMP-mediated signaling & 1.56 & 0.00913 & P2RY13, CCR4 \\
\hline G-protein-coupled receptor signaling & 1.44 & 0.00781 & P2RY13， CCR4 \\
\hline Complement system & 1.37 & 0.027 & $\mathrm{C} 1 \mathrm{QB}$ \\
\hline Mechanisms of viral exit from host cells & 1.32 & 0.0244 & PRKCQ \\
\hline Role of macrophages, fibroblasts, and endothelial cells in rheumatoid arthritis & 1.32 & 0.00671 & PRKCQ, IL1R2 \\
\hline UVC-induced MAPK signaling & 1.31 & 0.0238 & PRKCQ \\
\hline
\end{tabular}

Pathways and molecules are shown. Testing was based on the Fisher right-tailed exact test, and the $-\log (P$ value) was calculated (values $>1.3$ are equivalent of $P<0.05$ ). The ratio of the number of molecules in the data set, relative to the total number of molecules in that pathway, was calculated.

$\mathrm{BH}$, Benjamini-Hochberg correction; HAA0, 3-hydroxyanthranilate 3,4-dioxygenase; MAPK, mitogen-activated protein kinase.

with $\mathrm{dmPGE}_{2}$ or control medium was also investigated. The increased lactate measured in supernatants from BM cells pulsed with dmPGE 2 was no longer detected (Figure 5D).

\section{Reduced Migration and Enhanced Lactate Production by DCs from UV-Chimeric Mice}

Control- and UV-chimeric mice were established as previously reported. ${ }^{9}$ By 16 weeks after injection of $\mathrm{BM}$ cells, immune cells in the BM, spleen, and lymph nodes were $>95 \%$
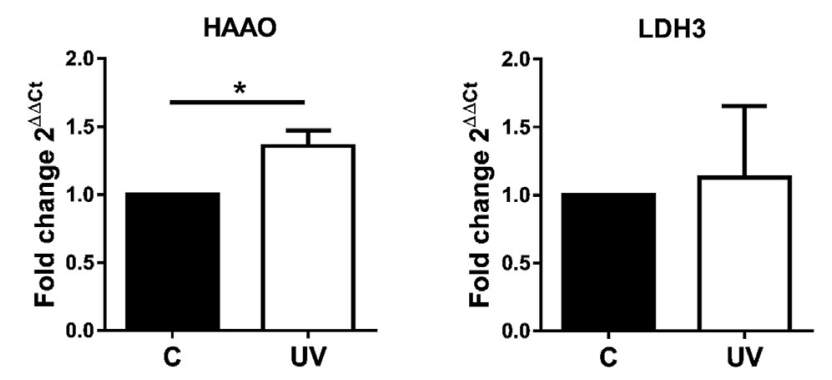

Figure 4 Confirmation by quantitative RT-PCR of increased HAAO expression by $\mathrm{CD}_{11 \mathrm{c}^{+}}$cells differentiated from the BM of UV-irradiated mice. RNA was extracted from $\mathrm{CD}_{11 \mathrm{c}^{+}}$cells differentiated from the BM of six nonirradiated and six UV-irradiated mice. Fold change of HAAO and lactate dehydrogenase $\mathrm{C}(\mathrm{LDH} 3)$ was determined by using the $2^{\Delta \Delta \mathrm{Ct}}$ method. Expression in cells from UV-irradiated mice (UV) has been normalized to that in cells from the nonirradiated mice $(C)$. Data are expressed as means \pm SEM. ${ }^{*} P<0.05$. of donor origin (CD45.1) and there were no differences between mice receiving cells from nonirradiated or UVirradiated donors (data not shown). We have previously published that $\mathrm{CD} 11 \mathrm{c}^{+}$cells differentiating from the BM of 16week engrafted UV-chimeric mice have poor priming ability compared with those differentiating from the BM of controlchimeric mice, when transferred into the ears of naive mice. ${ }^{9}$ A reduction in the priming ability of $\mathrm{CD} 11 \mathrm{c}^{+}$cells differentiating from the BM of the UV-chimeric mice was confirmed (Figure 6A). Consistent with this, significantly fewer CD11 $\mathrm{c}^{+}$ cells (Figure 6B) and macrophages (data not shown) were induced to collect in the peritoneal cavity of UV-chimeric mice compared with control-chimeric mice, 3 days after i.p. injection of the inflammatory stimulus, thioglycollate.

$\mathrm{CD} 11 \mathrm{c}^{+}$cells were also differentiated from the BM of eight pairs of UV-chimeric mice, each pair consisting of a control-chimeric mouse and a UV-chimeric mouse. CD11 $\mathrm{c}^{+}$ cells differentiated from the BM of UV-chimeric mice demonstrated increased lactate production, and the kinetics of lactate production confirmed that differences were not because of a delay in metabolite production (Figure 6C) (paired $t$-test $P=0.023$ ).

\section{Reduced Migration by DCs of $\mathrm{dmPGE}_{2}$-Chimeric Mice}

Further chimeric mice were established using bone marrow cells pulsed in vitro for 2 hours with $\mathrm{dmPGE}_{2}\left(\mathrm{dmPGE}_{2}-\right.$ 


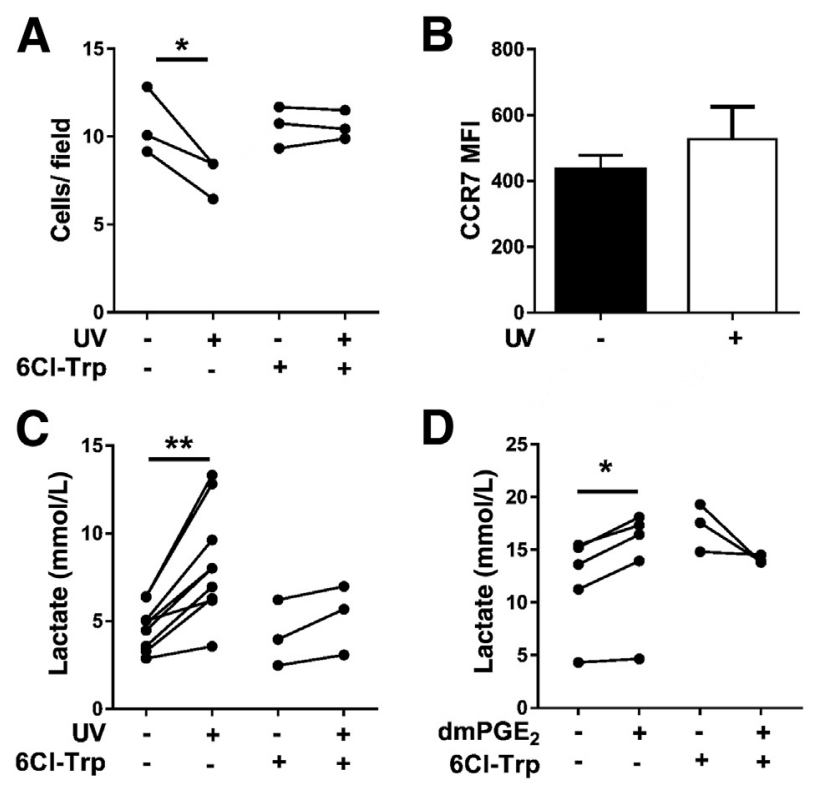

Figure 5 Reduced migration toward CCL21 by $\mathrm{CD} 11 \mathrm{c}^{+}$cells differentiated from the BM of UV-irradiated mice, or BM cells from naïve mice pulsed in vitro with dmPGE 2 . A: Effect of 6-chloro-DL-tryptophan (6Cl-Trp) on migration. BM-derived $\mathrm{CD} 11 \mathrm{c}^{+}$cells were obtained as for Figure $1 . \mathrm{CD}_{11 \mathrm{c}^{+}}$ cells differentiated from the BM of UV-irradiated mice were not as efficient as those from nonirradiated mice to migrate toward CCL21. Reduced migration toward CCL21 by CD11 $\mathrm{C}^{+}$cells differentiated from the BM of UVirradiated mice was restored by 30 minutes preincubation with $500 \mu \mathrm{mol} / \mathrm{L}$ $6 \mathrm{Cl}$-Trp. Each point represents $\mathrm{CD} 11 \mathrm{c}^{+}$cells from the BM of a single mouse (two filters, 10 images/filter). B: The expression of CCR7 on CD11 ${ }^{+}$cells differentiated from the BM of nonirradiated and UV-irradiated mice; the mean fluorescence intensity (MFI) on cells from five mice is shown. C: Effect of $6 \mathrm{Cl}$-Trp on lactate production. $\mathrm{CD}_{11 \mathrm{C}^{+}}$cells differentiated from the bone marrow of UV-irradiated or nonirradiated mice were incubated for 24 hours in medium containing $0.5 \%$ fetal calf serum (FCS). Lactate levels in the supernatants were measured; a mean value for cells from individual mice was calculated (mean of triplicate cultures/mouse). $\mathrm{CD}_{11 \mathrm{c}^{+}}$cells from three mice per group were preincubated with $500 \mu \mathrm{mol} / \mathrm{L} 6 \mathrm{Cl}$-Trp for 30 minutes at $37^{\circ} \mathrm{C}$. D: Effect of $6 \mathrm{Cl}-\mathrm{Trp}$ on lactate production by $\mathrm{CD}_{11 \mathrm{c}^{+}}$cells differentiated from BM cells pulsed in vitro with $\mathrm{dmPGE}_{2}$. CD11c $\mathrm{c}^{+}$cells were differentiated from $B M$ cells pulsed with $\mathrm{dmPGE}_{2}$ or control medium and then incubated for 24 hours in medium containing $0.5 \%$ FCS. Lactate levels in the supernatants were measured; a mean value for cells from individual

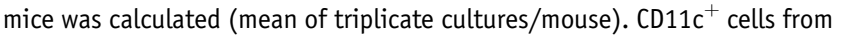
three mice per group were preincubated with $500 \mu \mathrm{mol} / \mathrm{L} 6 \mathrm{Cl}$-Trp for 30 minutes at $37^{\circ} \mathrm{C}$. Data are expressed as means + SEM (B). $n=9$ mice per group (C); $n=5$ mice per group (D). ${ }^{\star} P<0.05,{ }^{*} P<0.01$.

chimeric) or control medium (control-chimeric). A similar reduced priming ability was measured for $\mathrm{CD} 11 \mathrm{c}^{+}$cells differentiating from the $\mathrm{BM}$ of $\mathrm{dmPGE}_{2}$-chimeric mice, compared with those from control-chimeric mice (Figure 6D), and significantly fewer DCs accumulated in the peritoneal cavity of $\mathrm{dmPGE}_{2}$-chimeric mice after thioglycollate injection (Figure 6E). Expression levels of CCR2 and CCR7 on CD11c cells harvested from the peritoneal cavity of control- and $\mathrm{dmPGE}_{2}$-chimeric mice were not different (Figure 6F), a result supported by no differences in chemokine receptor expression in the microarray analysis.

\section{Discussion}

DCs differentiating from the BM of UV-irradiated mice, compared with those differentiating from the BM of nonirradiated (control) mice, were more glycolytic, as defined by an increased rate of lactate production, enhanced glucose use, and a greater response in a glycolytic stress test. The increased glycolytic response was not because of a reduction in oxidative phosphorylation as there were no significant differences detected in a mitochondrial stress test by DCs from the different mouse groups. Transcriptome analysis of these cells by microarray, and confirmation by RT-qPCR, revealed increased expression of HAAO in DCs differentiated from the $\mathrm{BM}$ of UV-irradiated mice. HAAO is an enzyme that catalyzes the opening of the oxidative ring of 3-hydroxyanthranilate in the final step of the biosynthetic pathway from tryptophan to quinolinate, the universal de novo precursor to the pyridine ring of NAD. ${ }^{26}$ Increased HAAO may, therefore, be involved in the bioenergetics of the DCs as a mechanism to regenerate NAD for continued glycolysis (Figure 7). NAD is a coenzyme found in all living cells that contributes to the maintenance of vital cellular functions. By increasing NAD, cells are less susceptible to oxidative $\operatorname{stress}^{27}$; an increased ratio of $\mathrm{NAD}^{+} / \mathrm{NADH}$ has been associated with increased aerobic glycolysis, and a reduced ratio with oxidative phosphorylation. ${ }^{28}$ Increased levels of nicotinamide per se have been associated with increased bioenergetics of cells, and nicotinamide supplementation can enhance the metabolic activity and survival of keratinocytes in UV-irradiated skin. ${ }^{29}$

It was necessary to determine the relevance of the increased glycolytic flux in the function of $\mathrm{CD} 11 \mathrm{c}^{+}$cells differentiated from the BM of UV-irradiated mice. For efficient priming of new immune responses, DCs must migrate to lymph nodes under the influence of CCR7binding chemokines. However, DCs from the BM of UVirradiated mice migrated poorly toward the chemokine CCL21. If HAAO activity was blocked, both the increased lactate produced by DCs from the BM of UV-irradiated mice and their reduced migration toward CCL21 were abrogated. In summary, we could functionally link increased HAAO activity with reduced migration. The reduced DC migration in vitro by cells from the BM of UVirradiated mice was recapitulated in vivo by the fewer $\mathrm{CD} 11 \mathrm{c}^{+}$cells collecting in the peritoneal cavity of UVchimeric mice after injection of inflammatory thioglycollate. In this important observation, DCs would have differentiated in vivo in response to physiological signals, not to GM-CSF and IL-4 added in vitro. In addition, we have previously published that DCs in the skin and trachea of UV-chimeric mice migrate more slowly than those in control-chimeric mice to draining nodes after activation by FITC and lipopolysaccharide, respectively. ${ }^{12}$

We had not hypothesized that increases in the glycolytic capacity of cells differentiating from the BM of UVirradiated mice would underpin their reduced ability to 

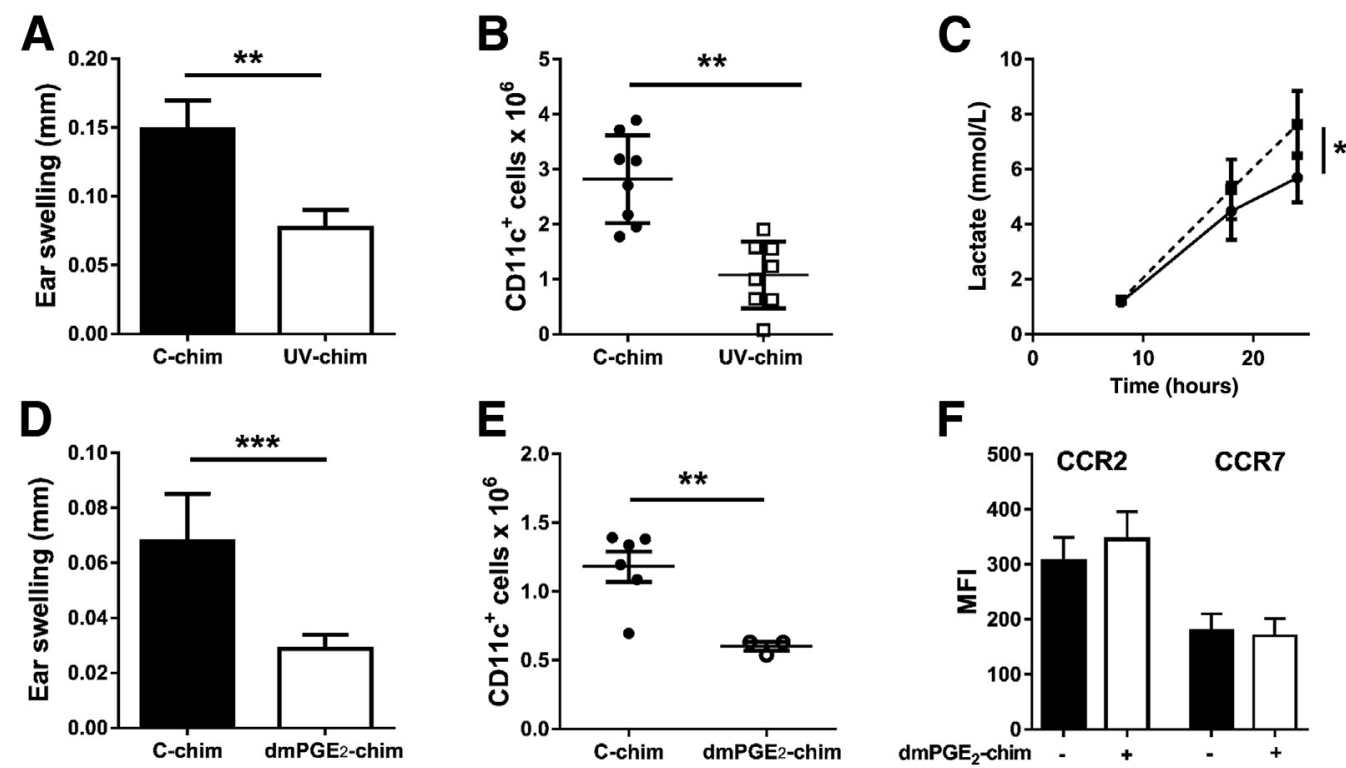

Figure 6 Studies in UV-chimeric (UV-chim) and dmPGE ${ }_{2}$-chimeric ( $\mathrm{dmPGE}_{2}$-chim) mice. A: Reduced priming ability of CD11c $\mathrm{c}^{+}$cells differentiated from the BM of UV-chim mice. CD11c ${ }^{+}$cells were purified from cultures of BM cells from control-chimeric (C-chim) and UV-chim mice. They were pulsed with $1 \mathrm{mmol} / \mathrm{L}$ 2,4-dinitrobenzene sulfonic acid before injection of $10^{6}$ cells into the ear pinnae of mice. After 7 days, the ears were painted with $10 \mu \mathrm{L} \mathrm{0.2 \%} \mathrm{2,4-dinitro-1-}$ fluorobenzene in acetone/olive oil (4:1). The ear thickness before painting of the chemical was subtracted from that measured after 24 hours. B: CD11 ${ }^{+}$cells harvested from the peritoneal cavity of 16-week engrafted C-chim and UV-chim mice 3 days after injection of an inflammatory reagent. Mice were injected i.p. with thioglycollate. The number of $\mathrm{CD}_{11} \mathrm{c}^{+}$cells harvested after 3 days from individual mice (closed circles, C-chim mice; open squares, UV-chim mice) is shown. C: Increased lactate production by $\mathrm{CD}_{11 \mathrm{c}^{+}}$cells differentiated from the BM of UV-chimeric mice. BM cells from C-chim and UV-chim mice were cultured with GM-CSF and IL-4 for differentiation of $\mathrm{CD} 11 \mathrm{c}^{+}$cells. Purified $\mathrm{CD} 11 \mathrm{c}^{+}$cells were incubated as triplicate wells for each time point in medium containing $0.5 \%$ fetal calf serum for up to 24 hours. The kinetics of lactate production for cells from C-chim mice are shown by circles and a solid line; those from UV-

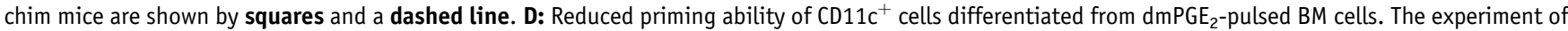

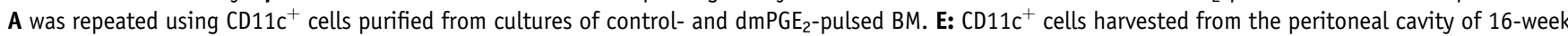
engrafted C-chim and dmPGE circles) were injected i.p. with thioglycollate. The number of $\mathrm{CD} 11 \mathrm{c}^{+}$cells harvested after 3 days from individual mice is shown. F: Expression of CCR2 and CCR7 on $\mathrm{CD}_{11 \mathrm{C}^{+}}$cells harvested from the peritoneal cavity of mice, as in $\mathbf{E}$. The expression of CCR2 and CCR7 on CD11c $\mathrm{c}^{+}$cells harvested from the peritoneal cavity, as described in E. Mean fluorescence intensity (MFI) is shown. Data are means \pm SEM (B, C, E, and $\mathbf{F}) . n=8$ ears per group $(\mathbf{A}) ; n=8$ mice per group $(\mathbf{B}) ; n=8$ C-chim mice and 8 UV-chim mice $(\mathbf{C}) ; n=6$ C-chim mice and $3 \mathrm{dmPGE}_{2}$-chim mice $(\mathbf{E}) .{ }^{*} P<0.05,{ }^{*} P<0.01$, and ${ }^{* * *} P<0.001$.

prime new responses, largely because of their slower migration to draining nodes. In this study, lactate production by $\mathrm{CD} 11 \mathrm{c}^{+}$cells differentiated from the $\mathrm{BM}$ of eight control- and eight UV-chimeric mice was also analyzed, with significantly greater lactate levels measured for those differentiating from the $\mathrm{BM}$ of UV-chimeric mice. The findings in UV-chimeric mice support the results detected in UV-irradiated mice, but also suggest that the basis for the increased glycolysis is long-lived, implying epigenetic changes to progenitor cells.

The outcomes in cells from the BM of UV-irradiated mice and UV-chimeric mice are similar to those recently published in reports of trained immunity. In this concept, there are memory characteristics in cells of the innate immune system. In the original observations, monocytes/ macrophages exposed to fungal $\beta$-glucan were trained such that their antibacterial defenses were increased on subsequent microorganism exposure. ${ }^{30,31}$ After further experimentation, it was demonstrated that trained immunity relates to a metabolic rewiring of the cells and an enhanced shift toward aerobic glycolysis, and greater lactate production, for provision of energy. ${ }^{28}$ The first studies of trained innate immunity involved a change to the cells themselves, and this change has been attributed to epigenetic programing of monocytes as they differentiate to macrophages. However, as the half-life of blood-derived myeloid cells is a matter of days (original studies were of macrophages 7 days after the initial fungal stimulus), and there can be longer-lasting effects of trained immunity for up to 12 months in humans, ${ }^{32}$ trained immunity must also be exerted at the level of BM myeloid cell progenitors. We believe studies on the metabolic profile of myeloid cells differentiating from the BM, the site of hematopoietic cell regeneration, have not been previously studied. We, ${ }^{9}$ and others, ${ }^{33}$ have reported trained immune function from BMdifferentiated myeloid cells, but this is the first report of altered migration capabilities associated with increased glycolytic capacity of DCs.

How a profile of increased glycolysis and lactate production relates to less migratory DCs is a matter of further debate. It is generally proposed that enhanced glycolysis is needed to generate sufficient ATP to keep DCs 


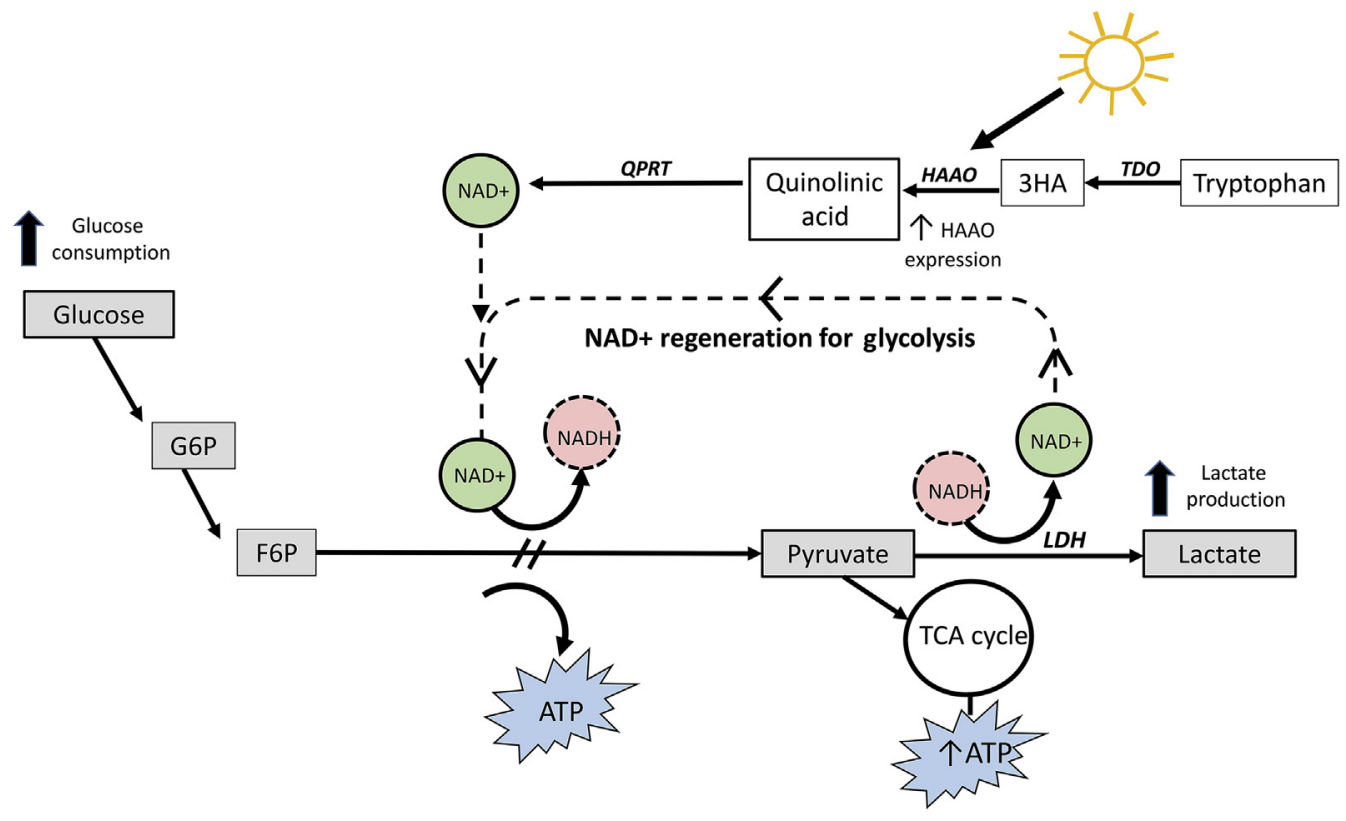

Figure 7 Overview of increased glycolytic activity in DCs differentiated from the BM of UV-irradiated mice. Glycolytic metabolism is maintained by the regeneration of $\mathrm{NAD}^{+}$from the reduced form, $\mathrm{NADH}$, as $\mathrm{NAD}^{+}$is reduced during the ATP generation stage of glycolysis. This is achieved by the conversion of pyruvate to lactate via lactate dehydrogenase (LDH); thus, cycling of glycolysis can continue provided glucose is available. In this study, an increase in glycolytic activity was reflected by increased glucose consumption, increased lactate production, and an enhanced ECAR response to glucose challenge. Furthermore, an elevation in 3-hydroxyanthranilate 3,4-dioxygenase (HAA0) expression was observed, which is an enzyme involved in tryptophan degradation to quinolinic acid, that can subsequently be used for generation of $N A D^{+}$via the enzyme quinolinic acid phophoribosyl transfers (QPRT). Thus, increased activity of HAAO may allow for additional $\mathrm{NAD}^{+}$required to maintain continuous cycling of glycolysis. Conical flasks represent sections of the metabolic pathway that were investigated in the current study. Diagonal lines between fructose-6-phosphate (F6P) and pyruvate indicate multiple reactions and enzymes leading to pyruvate and ATP formation. 3HA, 3-hydroxy-anthrananilic acid; G6P, glucose-6-phosphate; TCA, tricarboxylic acid cycle; TD0, tryptophan-2, 3-dioxygenase.

functioning. ${ }^{3-5}$ Enhanced glycolysis is required because the production of nitric oxide in DCs disables oxidative phosphorylation in the mitochondria. ${ }^{34}$ In one study comparing immunogenic and tolerogenic DC activation states, tolerogenic DCs displayed a markedly augmented catabolic pathway related to glycolysis, oxidative phosphorylation, and fatty acid metabolism. ${ }^{35}$ For glycolysis, they found that tolerogenic and mature DCs show similar glycolytic rates, but glycolytic capacity and reserve is more pronounced in the tolerogenic DCs. ${ }^{35}$ Our study used similar technology and bioenergetics measurements using the Seahorse $\mathrm{XF}^{\mathrm{e}} 96$ Extracellular Flux Analyzer. Furthermore, our less immunogenic cells from the BM of UV-irradiated mice had significantly increased glycolytic capacity and glycolytic reserve.

The expression of HAAO, the final enzyme involved in the tryptophan to quinolinate biosynthetic pathway ${ }^{26}$ (Figure 7), has previously been studied in DCs as part of a cluster of genes involved in tryptophan metabolism. ${ }^{36}$ During DC maturation, indoleamine dioxygenase is a strongly up-regulated gene, together with those for tryptophanyl tRNA synthetase, kynurenine monoxygenase, and kynureninase. However, in contrast to the increased transcription of these genes during DC maturation, HAAO is not induced and suggests that changes in HAAO mRNA detected by both array and RT-qPCR do not relate to changes in DC maturation. Instead, the increased levels of HAAO mRNA may reflect epigenetic regulation of this gene after UV irradiation of the skin. ${ }^{37}$

Either implantation of skin by pellets releasing $\mathrm{PGE}_{2}$ or in vitro pulsing of $\mathrm{BM}$ cells with $\mathrm{dmPGE}_{2}$ had a similar effect on lactate production by BM-differentiated DCs, as was measured for DCs differentiating from the BM of UV-irradiated mice. The difference in lactate production by $\mathrm{DCs}$ differentiating from $\mathrm{dmPGE}_{2^{-}}$and control medium-pulsed BM cells was removed by exposure to the HAAO inhibitor, 6-chloro-DL-tryptophan. When dmPGE $2_{2}^{-}$ chimeric mice were established, DCs differentiating from the $\mathrm{BM}$ in vitro were poor in priming new responses, whereas those differentiating from the BM in vivo did not efficiently accumulate in the peritoneal cavity after injection of an inflammatory stimulus. The data did not support differences in chemokine receptor expression but instead suggested an inherent difference in motility by DCs in the $\mathrm{dmPGE}_{2}$-chimeric mice. These results support the proposal that UV-induced $\mathrm{PGE}_{2}$ is an active mediator in the sustained effects of UVR on BM cells. ${ }^{8,12}$ We have previously shown that an epigenetic event may be involved; the effect of UVR on BM-differentiated DCs was removed by peritoneal injections of 5-aza-2-deoxycytidine, an inhibitor of DNA methylation. ${ }^{9,38}$ How $\mathrm{PGE}_{2}$ alters progenitor DCs is a matter of ongoing research, although it is clear that 
hematopoietic stem cells can respond via their EP4 receptor to $\mathrm{PGE}_{2} \cdot{ }^{39-42} \mathrm{PGE}_{2}$ can stimulate DNA methyltransferases $^{43}$ and can support the concept of $\mathrm{PGE}_{2-}$ dependent epigenetic (methylation) changes to DC progenitors.

In conclusion, DCs differentiating from the BM of UVirradiated mice have a significantly increased glycolytic response to stress, which supports the finding of increased lactate production by these cells. In microarrays, confirmed by RT-qPCR, there was an associated increase in the mRNA levels for HAAO, an enzyme that can be plausibly linked to increased and continued glycolysis (Figure 7). As DC ability to initiate new immune responses depends on an ability to migrate to lymph nodes, we sought a relationship between the increased glycolytic flux and DC motility in a chemokine gradient. Increased HAAO activity because of UV exposure of BM-donor mice associated with slower migration to CCL21 as inhibition of HAAO blocked UVinduced changes in migration and lactate production. Determination of the relationship between increased glycolysis and reduced motility of DCs differentiated from the BM of UV-irradiated mice, or BM cells pulsed for 2 hours with $\mathrm{dmPGE}_{2}$, must be the subject of further investigation. The importance of small differences in DC migration in vitro was highlighted by the amplification of the effect by the significant differences in accumulation of DCs in the peritoneal cavity of the UV-chimeric and $\mathrm{dmPGE}_{2}$-chimeric mice compared with control-chimeric mice after injection of thioglycollate. It is also unknown whether DC functions in addition to reduced motility are affected by UV irradiation of skin. This study teaches us that there is no typical ground state of activity of BM-derived DCs, and the baseline characteristics (in this study, metabolic activities) may vary as part of a spectrum of phenotypes. One of those factors that may control the baseline metabolism and associated function of DCs is skin exposure to erythemal amounts of UV irradiation by pathways involving $\mathrm{PGE}_{2}$.

\section{Acknowledgments}

We thank Deborah Strickland and Jason Waithman for assistance in generating the chimeric mice, and Bright Blue for the donation of the Nikon C2 Confocal Microscope.

T.A.M., K.N.K., H.S.G., P.N., and P.H.H. designed the study; T.A.M., K.N.K., N.M.S., and S.G. performed experiments; K.W.C. and D.A. analyzed microarray data; F.J.P., A.D., and E.G. assisted with establishment of migration assays; and all authors approved the final version of the article.

\section{References}

1. Satpathy AT, Wu X, Albring JC, Murphy KM: Re(de)fining the dendritic cell lineage. Nat Immunol 2012, 13:1145-1154
2. Kawai T, Akira S: Toll-like receptors and their crosstalk with other innate receptors in infection and immunity. Immunity 2011, 34: 637-650

3. Everts B, Amiel E, Huang SCC, Smith AM, Chang CH, Lam WY, Redmann V, Freitas TC, Blagih J, van der Windt GJW, Artyomov MN, Jones RG, Pearce EL, Pearce EJ: TLR-driven early glycolytic reprogramming via the kinases TBK1-IKKe supports the anabolic demands of dendritic cell activation. Nat Immunol 2014, 15: 323-332

4. Everts B, Pearce EJ: Metabolic control of dendritic cell activation and function: recent advances and clinical implications. Front Immunol 2014, 5:1-7

5. Pearce EJ, Everts B: Dendritic cell metabolism. Nat Rev Immunol $2015,15: 18-29$

6. Hart PH, Gorman S, Finlay-Jones JJ: Modulation of the immune system by UV radiation: more than just the effects of vitamin D? Nat Rev Immunol 2011, 11:584-596

7. Ullrich SE, Byrne SN: The immunologic revolution: photoimmunology. J Invest Dermatol 2012, 132:896-905

8. Ng RLX, Bisley JL, Gorman S, Norval M, Hart PH: UV-irradiation of mice reduces the competency of BM-derived $\mathrm{CD} 11 \mathrm{c}+$ cells via an indomethacin-inhibitable pathway. J Immunol 2010, 185:7207-7215

9. Ng RLX, Scott NM, Strickland DH, Gorman S, Grimbaldeston MA, Norval M, Waithman J, Hart PH: Altered immunity and dendritic cell activity in the periphery of mice after long-term engraftment with bone marrow from UV-irradiated mice. J Immunol 2013, 190:5471-5484

10. Ng RLX, Scott NM, Bisley JL, Lambert MJ, Gorman S, Hart PH: Characterisation of regulatory dendritic cells differentiated from the bone marrow of UV-irradiated mice. Immunology 2013, 140:399-412

11. Hoeffel G, Wang Y, Greter M, See P, Teo P, Malleret B, Leboeuf M, Low D, Oller G, Almeida F, Choy SHY, Grisotto M, Renia L, Conway SJ, Stanley ER, Chan JKY, Ng LG, Samokhvalov IM, Merad M, Ginhoux F: Adult Langerhans cells derive predominantly from embryonic fetal liver monocytes with a minor contribution of yolk sac-derived macrophages. J Exp Med 2012, 209:1167-1181

12. Scott NM, Ng RLX, Gorman S, Norval M, Waithman J, Hart PH: Prostaglandin $\mathrm{E}_{2}$ imprints a long-lasting effect on dendritic cell progenitors in the bone marrow. J Leukoc Biol 2014, 95:225-232

13. Hart PH, Grimbaldeston MA, Swift GJ, Jaksic A, Noonan FP, FinlayJones JJ: Dermal mast cells determine susceptibility to ultraviolet B-induced systemic suppression of contact hypersensitivity responses in mice. J Exp Med 1998, 187:2045-2053

14. Cutler C, Multani P, Robbins D, Kim HT, Le T, Hoggatt J, Pelus LM, Desponts C, Chen YB, Rezner B, Armand P, Koreth J, Glotzbecker B, Ho VT, Alyea E, Isom M, Kao G, Armant M, Silberstein L, Hu P, Soiffer RJ, Scadden DT, Ritz J, Goessling W, North TE, Mendlein J, Ballen K, Zon LI, Antin JH, Shoemaker DD: Prostaglandin-modulated umbilical cord blood hematopoietic stem cell transplantation. Blood 2013, 122:3074-3081

15. Helft J, Bottcher J, Chakravarty P, Zelenay S, Huotari J, Schraml BU, Goubau D, Reis e Sousa C: GM-CSF mouse bone marrow cultures comprise a heterogeneous population of $\mathrm{CD} 11 \mathrm{c}+\mathrm{MHCII}+$ macrophages and dendritic cells. Immunity 2015, 42:1197-1211

16. Saito K, Chen CY, Masana M, Crowley JS, Markey SP, Heyes MP: 4Chloro-3-hydroxyanthranilate, 6-chlorotryptophan and norharmane attenuate quinolinic acid formation by interferon-g-stimulated monocytes (THP-1 cells). Biochem J 1993, 291:11-14

17. Keane KN, Calton EK, Cruzat VF, Soares MJ, Newsholme P: The impact of cryopreservation on human peripheral blood leucocyte bioenergetics. Clin Sci (Lond) 2015, 128:723-733

18. Krause M, Keane K, Rodrigues-Krause J, Crognale D, Egan B, De Vito G, Murphy C, Newsholme P: Elevated levels of extracellular heatshock protein 72 (eHSP72) are positively correlated with insulin resistance in vivo and cause pancreatic $\beta$-cell dysfunction and death in vitro. Clin Sci (Lond) 2014, 126:739-752

19. Carvalho BS, Irizarry RA: A framework for oligonucleotide microarray preprocessing. Bioinformatics 2010, 26:2363-2367 
20. Kauffmann A, Gentleman R, Huber W: ArrayQualityMetrics: a bioconductor package for quality assessment of microarray data. Bioinformatics 2009, 25:415-416

21. Ritchie ME, Phipson B, Wu D, Hu Y, Law CW, Shi W, Smyth GK: Limma powers differential expression analyses for RNA-sequencing and microarray studies. Nucleic Acids Res 2015, 43:e47

22. Benjamini Y, Hochberg Y: Controlling the false discovery rate: a practical and powerful approach to multiple testing. J R Statist Soc B 1995, 57:289-300

23. Riol-Blanco L, Sánchez-Sánchez N, Torres A, Tejedor A, Narumiya S, Corbí AL, Sánchez-Mateos P, Rodríguez-Fernández JL: The chemokine receptor CCR7 activates in dendritic cells two signaling modules that independently regulate chemotaxis and migratory speed. J Immunol 2005, 174:4070-4080

24. Eid Bou Ghosn E, Cassado AA, Govoni GR, Fukuhara T, Yang Y, Monack DM, Bortoluci KR, Almeida SR, Herzenberg LA, Herzenberg LA: Two physically, functionally, and developmentally distinct peritoneal macrophage subsets. Proc Natl Acad Sci U S A 2010, 107:2568-2573

25. Newsholme P, Curi R, Gordon S, Newsholme EA: Metabolism of glucose, glutamine, long-chain fatty acids and ketone bodies by murine macrophages. Biochem J 1986, 239:121-125

26. Zhang Y, Colabroy KL, Begley TP, Ealick SE: Structural studies of 3hydroxyanthranilate-3,4-dioxygenase: the catalytic mechanism of a complex oxidation involved in NAD biosynthesis. Biochemistry 2005, 44:7632-7643

27. Hu Y, Wang H, Wang Q, Deng H: Overexpression of CD38 decreases cellular NAD levels and alters the expression of proteins involved in energy metabolism and antioxidant defense. J Proteome Res 2014, 13: 786-795

28. Cheng S-C, Quintin J, Cramer RA, Shepardson KM, Saed S, Kumar V, Giamarellos-Bourboulis EJ, Martens JHA, Rao NA, Aghajanirefah A, Manjeri GR, Li Y, Ifrim DC, Arts RJW, van der Veer BMJW, Deen PMT, Logie C, O'Neill LA, Willems P, van de Veerdonk FL, van der Meer JWM, Ng A, Joosten LAB, Wijmenga C, Stunnenberg HG, Xavier RJ, Netea MG: mTOR- and HIF-1a-mediated aerobic glycolysis as metabolic basis for trained immunity. Science 2015, 345:1250684

29. Surjana D, Halliday GM, Martin AJ, Moloney FJ, Damian DL: Oral nicotinamide reduces actinic keratosis in phase II double-blinded randomized controlled trials. J Invest Dermatol 2012, 132:1497-1500

30. Quintin J, Cheng SC, van der Meer JWM, Netea MG: Innate immune memory: towards a better understanding of host defense mechanisms. Curr Opin Immunol 2014, 29:1-7

31. Saeed S, Quintin J, Kerstens HHD, Rao NA, Aghajanirefah A, Matarese AF, Cheng SC, Ratter J, Berentsen K, van der Ent MA, Sharifi N, Janssen-Megens EM, Huurne MT, Mandoli A, van Schaik T, Ng A, Burden F, Downes K, Rontini M, Kumar V, GiamarellosBourboulis EJ, Ouwehand WH, van der Meer JWM, Joosten LAB, Wijmenga C, Martens JHA, Xavier RJ, Logie C, Netea MG, Stunnenberg HG: Epigenetic programming of monocyte-to- macrophage differentiation and trained innate immunity. Science 2014, 345:1251086

32. Kleinnijenhuis J, Quintin J, Preijers F, Benn CS, Joosten LA, Jacobs C, van Loenhout J, Xavier RJ, Aaby P, van der Meer JW, van Crevel R, Netea MG: Long-lasting effects of BCG vaccination on both heterologous Th1/Th17 responses and innate trained immunity. J Innate Immun 2014, 6:152-158

33. Yanez A, Hassanzadeh-Kiabi N, Ng MY, Megias J, Subramanian A, Liu GY, Underhill DM, Gil ML, Goodridge HS: Detection of a TLR2 agonist by HSPCs impacts the function of the macrophages they produce. Eur J Immunol 2013, 43:2114-2125

34. Everts B, Amiel E, van der Windt GJW, Freitas TC, Chott R, Yarasheski KE, Pearce EL, Pearce EJ: Commitment to glycolysis sustains survival of NO-producing inflammatory dendritic cells. Blood 2012, 120:1422-1431

35. Malinarich F, Duan K, Hamid RA, Bijin A, Lin WX, Poidinger M, Fairhurst AM, Connolly JE: High mitochondrial respiration and glycolytic capacity represent a metabolic phenotype of human tolerogenic dendritic cells. J Immunol 2015, 194:5174-5186

36. Mcllroy D, Tanguy-Royer S, Le Meur N, Guisle I, Royer PJ, Leger J, Meflah K, Gregoire M: Profiling dendritic cell maturation with dedicated microarrays. J Leukoc Biol 2005, 78:794-803

37. Donohoe DR, Bultman SJ: Metaboloepigenetics: interrelationships between energy metabolism and epigenetic control of gene expression. J Cell Physiol 2012, 227:3169-3177

38. Juttermann R, Li E, Jaenisch R: Toxicity of 5-aza-2'-deoxycytidine to mammalian cells is mediated primarily by covalent trapping of DNA methyltransferase rather than DNA demethylation. Proc Natl Acad Sci U S A 1994, 91:11797-11801

39. Frisch BJ, Porter RL, Gigliotti BJ, Olm-Shipman AJ, Weber JM, O'Keefe RJ, Jordan CT, Calvi LM: In vivo prostaglandin $\mathrm{E}_{2}$ treatment alters the bone marrow microenvironment and preferentially expands short-term hematopoietic stem cells. Blood 2009, 114: 4054-4063

40. Pelus LM, Hoggatt J: Pleiotropic effects of prostaglandin $E_{2}$ in hematopoiesis: prostaglandin E2 and other eicosanoids regulate hematopoietic stem and progenitor cell function. Prostaglandins Other Lipid Mediat 2011, 96:3-9

41. Ikushima YM, Arai F, Hosokawa K, Toyama H, Takubo K, Furuyashiki T, Narumiya S, Suda T: Prostaglandin $\mathrm{E}_{2}$ regulates murine hematopoietic stem/progenitor cells directly via EP4 receptor and indirectly through mesenchymal progenitor cells. Blood 2013, 121:1995-2007

42. Hoggatt J, Mohammad KS, Singh P, Hoggatt AF, Chitteti BR, Speth JM, Hu P, Poteat BA, Stilger KN, Ferraro F, Silberstein L, Wong FK, Farag SS, Czader M, Milne GL, Breyer RM, Serezani CH, Scadden DT, Guise TA, Srour EF, Pelus LM: Differential stem- and progenitor-cell trafficking by prostaglandin $E_{2}$. Nature 2013, 495: 365-369

43. Xia D, Wang D, Kim SH, Katoh H, DuBois RN: Prostaglandin $E_{2}$ promotes intestinal tumor growth via DNA methylation. Nat Med 2012, 18:224-226 